[Vol. 127:494

\title{
COMMENTS
}

\section{THE EQUAL RIGHTS AMENDMENT AND ARTICLE V: A FRAMEWORK FOR ANALYSIS OF THE EXTENSION AND RESCISSION ISSUES}

\section{INTRODUCTION}

Article $\mathrm{V}$ of the United States Constitution, ${ }^{1}$ which provides procedures for constitutional amendment, has rarely been analyzed, either by commentators ${ }^{2}$ or by the judiciary. ${ }^{3}$ The recent debate surrounding the ratification of the Equal Rights Amendment ${ }^{4}$ [hereinafter "ERA"], and, in particular, the attempts by some states to rescind prior ratifications ${ }^{5}$ have, however, generated much comment. ${ }^{6}$ These discussions, which have proceeded primarily from a

1 See text accompanying note 19 infra.

2 For one of the few extensive treatments of article $V$ see $L$. OAFIELD, AMENDING THE FEDERAL CoNstitution (1942).

3 Those cases that specifically construe article $V$ are Coleman v. Miller, 307 U.S. 433 (1939) (prior rejection of proposed amendment by state legislature does not prohibit subsequent ratification; determination of reasonable time period for ratification is a political question); United States v. Sprague, 282 U.S. 716 (1931) (article V places choice of method of ratification within the sole discretion of Congress and does not require that amendments granting new direct powers over individuals be ratified in conventions); Leser v. Garnett, 258 U.S. 130 (1922) (amendments that increase the size of the electorate are within the amending power of article V); Dillon v. Gloss, 256 U.S. 368 (1921) (Congress may constitutionally limit ratification period); National Prohibition Cases, 253 U.S. 350 (1920) (Congress's action in proposing an amendment is sufficient indication of congressional determination of its necessity: no express declaration is necessary); Hawke v. Smith, 253 U.S. 221 (1920) (article V does not permit use of binding referendum to determine state ratification of proposed amendment); Hollingsworth v. Virginia, 3 U.S. ( 3 Dall.) 378 ( 1798 ) (Constitution does not require presidential approval of proposed amendments).

4 See note 7 infra.

5 Idaho, Nebraska, Tennessee, and Kentucky have passed resolutions rescinding their ERA ratifications. N.Y. Times, May 28, 1978, at A44, col. 2. The situation is further complicated in Kentucky, where the lieutenant governor vetoed the rescission resolution. Id. Further attempts at rescission may be forthcoming. See N.Y. Times, Feb. 17, 1978, at 18, col. 1.

${ }^{6}$ See $_{3}$ e.g., Burke, Validity of Attempts to Rescind Ratification of the Equal Rights Amendment, 8 U.W.L.A. L. Rev. 1 (1976); Elder, Article V, Justiciability, and the Equal Rights Amendment, 31 OkLA. L. Rev. 63 (1978); Heckman, Ratification of a Constitutional Amendment: Can a State Change Its Mind?, 6 ConN. L. Rev. 28 (1973); Kanowitz \& Klinger, Can a State Rescind Its Equal Rights Amendment Ratification: Who Decides and How?, 28 Hastrscs L. J. 979 (1977); Note, Reversals in the Federal Constitutional Amendment Process: Efficacy of State Ratifications of the Equal Rights Amendment, 49 IND. L.J. 147 (1973) [hereinafter cited as Reversals]; Comment, Rescinding Ratification of Proposed Constitutional Amendments-A Question for the Court, 37 LA. L. REv. 896 (1977); Note, The Equal Rights Amendment: Will States Be Allowed to Change Their Minds?, 49 Notre DAME LAw. 657 (1974); Comment, Constitutional AmendmentsThe Justiciability of Ratification and Retraction, 41 TENN. L. REv. 93 (1973). 
historical perspective using the sketchy case law that is available, have generally proved inconclusive. Rather than revisit ground that others have thoroughly covered, this Comment attempts, instead, to discern the meaning of article $V$ by offering a framework for its interpretation and application.

The joint resolution proposing the ERA, ${ }^{7}$ passed by Congress on March 22, 1972,8 limited the ratification period to seven years. Although thirty-five of the required thirty-eight states have ratified the proposed amendment, ${ }^{9}$ it is doubtful that three additional states would have done so before the original March 22, 1979 deadline. ${ }^{10}$ Accordingly, Congress has passed a resolution extending the ratiflcation deadline for thirty-nine additional months. ${ }^{11}$ Complicating

${ }^{7}$ H.R.J. Res. 208, 92d Cong., 2d Sess., 86 Stat. 1523 (1972). The text of the resolution states:

Resolved by the Senate and House of Representatives of the United States of America in Congress assembled (two-thirds of each House concurring therein), That the following article is proposed as an amendment to the Constitution of the United States, which shall be valid to all intents and purposes as part of the Constitution when ratified by the legislatures of three-fourths of the several States within seven years from the date of its submission by the Congress:

\section{"Article-}

"Section 1. Equality of rights under the law shall not be denied or abridged by the United States or by any State on account of sex.

"Sec. 2. The Congress shall have the power to enforce, by appropriate legislation, the provisions of this article.

"Sec. 3. This amendment shall take effect two years after the date of ratification."

(Emphasis of time limitation clause added).

$s$ The joint resolution proposing the ERA was passed by the House of Representatives on October 12, 1971, by a vote of 354 to 24, H.R.J. Res. 208, $92 d$ Cong., Ist Sess., 117 Cong. Rec. 35,815 (1971), 86 Stat. 1523 (1972). The Senate approved the resolution on March 22, 1972, by a margin of 84 to 8, S.J. Res. No. 8, 92d Cong., 2d Sess., 188 Cong. Rec. 9598 (1972).

9 These states are: Alaska, California, Colorado, Connecticut, Delaware, Hawaii, Idaho, Indiana, Iowa, Kansas, Kentucky, Maine, Maryland, Massachusetts, Michigan, Minnesota, Montana, Nebraska, New Hampshire, New Jersey, New Mexico, New York, North Dakota, Ohio, Oregon, Pennsylvania, Rhode Island, South Dakota, Tennessee, Texas, Vermont, Washington, West Virginia, Wisconsin, and Wyoming. Kanowitz \& Klinger, supra note 6, at 980 n.5; N.Y. Times, Jan. 19, 1977, at A14, col. 1 .

${ }^{10}$ See Kanowitz \& Klinger, supra note 6, at 981 ; cf. N.Y. Times, Apr. 16, 1978, $\$ 4$, at 18 , col. 1 (criticizing extension movement and urging political action to gain adoption by the deadline).

11 H.R.J. Res. 638, 95th Cong., 2d Sess. (1978):

Resolved by the Senate and House of Representatives of the United States of America in Congress assembled, That notwithstanding any provision of House Joint Resolution 208 of the Ninety-second Congress, second session, to the contrary, the article of amendment proposed to the States in such joint resolution shall be valid to all intents and purposes as part of the Constitution when ratified by the legislatures of three-fourths of the several States not later than June 30, 1982. 
the situation are the decisions of four state legislatures to rescind prior ratifications. ${ }^{12}$

Circumscribing the politics of the extension and rescission issues are questions of constitutional import. Although Congress may establish a deadline for the ratification of a proposed constitutional amendment, ${ }^{13}$ its authority to extend such a deadline is unclear. ${ }^{14}$ Rescission presents a similarly murky picture, particularly when paired with the extension question. Although commentators have long speculated that state legislatures lack constitutional authority to rescind prior ratifications, ${ }^{15}$ it has been argued that congressional extension of the ratification deadline would (or should) implicitly authorize such rescissions. ${ }^{16}$ The ultimate fate of the ERA depends in large measure upon the resolution of these issues.

This Comment will explore the constitutional dimensions of this most recent round of ERA politics, suggesting a framework for the analysis of the extension and rescission issues. Whether Congress has the power to extend the ratification deadline or whether state legislatures can rescind prior ratifications must turn on an interpretation of the source of the constitutional amending porver, article $V$ of the Constitution. ${ }^{17}$ Thus this Comment will focus on article $V$, examining first its express language and the framers' values implicit in that language or discoverable from historical sources. Moreover, because the Constitution is a living document, "intended to endure for ages to come, and, consequently, to be

The House of Representatives passed the resolution on August 15, 1978, by a vote of 233 to 189 . 124 CoNG. REc. H8664-65 (daily ed. Aug. 15, 1978). The Senate approved it on October 6,1978 , by a vote of 60 to 36.124 Cong. Rec. S17,318-19 (daily ed. Oct. 6, 1978).

12 See note 5 supra.

Both Houses rejected amendments to the extension resolution that would have allowed rescission. 124 Cong. REc. H8658 (daily ed. Aug. 15, 1978); 124 Cong. REC. S16,946 (daily ed. Oct. 3, 1978); 124 CONG. REc. S17,031, S17,048 (daily ed. Oct. 4, 1978). An eventual decision to allow rescission is not, however, precluded. See Equal Rights Amendment Extension: Hearings on H.J. Res. 638 Before the Subcomm. on Civil and Constitutional Rights of the House Comm. on the Judiciary, 95th Cong., Ist \& 2d Sess. (1977-1978) [hereinafter cited as Hearings], at 46 (testimony of Laurence $H$. Tribe). Professor Tribe stated: "It seems to me that this sort of judgment [i.e., whether rescission should be recognized] can only be made finally at the time a given Congress votes to decide whether an amendment has been validly ratified."

13 Dillon v. Gloss, 256 U.S. 368 (1921).

14 See generally Hearings, supra note 12.

15 E.g., J. Jameson, A Treatise on Constitutionar Conventions 629-33 (4th ed. 1887). Jr.).

${ }^{16}$ See, e.g., Hearings, supra note 12, at 68-69 (statement of Charles L. Black,

17 See text accompanying note 19 infra. 
adapted to the various crises of human affairs," 18 a thorough analysis must include fundamental political values of contemporary relevance as well.

Once those values that give meaning to article $V$ have been articulated, they must be examined in light of the constitutional questions at issue: will extension of the time limitation for ratification of a constitutional amendment or rescission of a previous ratification significantly advance or retard the value under consideration? Moreover, the various values must be compared with one another: a given action may significantly advance one value while simultaneously retarding another, necessitating a choice among values. Thus the ultimate constitutional interpreter must balance the relevant values in order to give meaning to article $\mathrm{V}$.

An equally fundamental question inherent in the ERA controversy is the identity of that ultimate decisionmaker: which branch of government will determine whether extension and/or rescission are constitutionally permissible? The concluding section of this Comment therefore focuses on the appropriate role of the courts in reviewing issues arising from the amendatory process.

\section{FrameWORK FOR INTERPRETATION}

\section{A. Framers' Values}

\section{Origin}

An analysis of the extension and rescission issues must begin with the source of constitutional amending power, article $V$ of the Constitution:

The Congress, whenever two thirds of both Houses shall deem it necessary, shall propose Amendments to this Constitution, or on the Application of the Legislatures of two thirds of the several States, shall call a Convention for proposing Amendments, which, in either Case, shall be valid to all Intents and Purposes, as Part of this Constitution, when ratified by the Legislatures of three fourths of the several States, or by Conventions in three fourths thereof, as the one or the other Mode of Ratification may be proposed by the Congress; Provided that no Amendment which may be made prior to the Year One thousand eight hundred and eight shall in any Manner affect the first and fourth Clauses in the Ninth Section of the first Article; and that no State, without its Consent, shall be deprived of its equal Suffrage in the Senate. ${ }^{19}$

19 U.S. Const. art. V. 
It is clear that the text of article $\mathrm{V}$ does not expressly ${ }^{20}$ address the issue of extension ${ }^{21}$ or that of rescission. ${ }^{22}$ Because the traditional method of constitutional interpretation imputes meaning to the Constitution by attempting to ascertain the intentions of the

20 Although the text of article $V$ addresses neither extension nor rescission, various inferences have been drawn as to its meaning. It can be argued, for example, that Congress cannot extend the deadline for ratification because its role in the amending process is limited to the "proposal" of an amendment, the power to choose the mode of ratification being merely a ministerial function. See Memorandum from John M. Harmon, Assistant Attorney General, to the Hon. Robert J. Lipshultz, Counsel to the President, on the Constitutionality of Extending the Time Period for Ratification of the Proposed Equal Rights Amendment (Oct. 31, 1977) [hereinafter cited as Memo], reprinted in Hearings, supra note 12, at 7, 9-10; Heckman, supra note 6 , at 29 . On the other hand, it can also be argued that these duties evidence a "wide range of [congressional] power" in proposing amendments, Dillon v. Gloss, 256 U.S. 368, 373 (1921), which includes the power to establish and extend a deadline for ratification. See generally Memo, supra. - Similarly, it has been suggested that article V's "when ratified" language implicitly restricts to ratification any state's involvement in the amending process. E.g., J. JAMESON, supra note 15, at 631-33. Conversely, it can be argued that, read in context, the word "ratified" is directed solely at the contemporaneity of ratification, cf. Dillon v. Gloss, 256 U.S. 368,375 (1921) ("ratification must be within some reasonable time after the proposal"), and therefore implies nothing about the power of rescission.

21 Indeed, imposition of a seven-year limit on the ratification period is a relatively recent development. It was first used for the eighteenth amendment, proposed in 1917. Dillon v. Gloss, 256 U.S. 368, 371-72 (1921). Since then, limitations have been imposed on the ratification periods of all but two proposed amendments: the nineteenth amendment, and the never ratified child labor amendment, H.R.J. Res. 184, 68th Cong., 1st Sess., 43 Stat. 670 (1924). See Memo, supra note 20, in Hearings, supra note 12 , at 9,12 . The original practice was to include the time limitation within the body of the amendment itself. Subsequent practice, after the proposal of the twenty-second amendment, has been to place the limitation within the resolution proposing the amendment rather than within the text of the amendment. See, e.g., H.R.J. Res. 208, 92d Cong., 2d Sess., 86 Stat. 1523 (1972) (proposing ratification of the ERA).

Some have used the placement of the time limitation to argue that only a majority, rather than a two-thirds, vote of each house is necessary to extend the ratification period for the ERA. See Hearings, supra note 12, at 39 (statement of Laurence $H$. Tribe). This controversy may become heated, as the extension resolution was passed by less than two-thirds of each house. See note 11 supra. To the extent that Congress's proposal of time limitations stems from its article $V$ power to propose necessary and effective changes, such limitations are arguably bound by the two-thirds requirement.

A related question is whether the extension resolution must be submitted to the President for signature. See Black, On Article I, Section 7, Clause 3-and the Amendment of the Constitution, 87 YALE L.J. 896 (1978) [hereinafter cited as On Article $I(7)(3)]$. President Carter has, however, signed the ERA extension resolution. See TIME, Oct. 23, 1978, at 32. Thus, at least in the context of the ERA, the issue has become moot.

22 Prior to the ERA, states rarely attempted to rescind ratifications of proposed amendments, doing so only with regard to the fourteenth, fifteenth, and nineteenth amendments. See Note, Reversals, supra note 6, at 150. While the popular perception appears to be that rescission is barred, see, e.g., Memo, supra note 20 , in Hearings, supra note 12 , at 9 , its historical precedent is cloaked in confusion. Compare, e.g., the analysis of the ratification of the fourteenth amendment in Coleman v. Miller, 307 U.S. 433, 449 (1939) with that offered in Corwin \& Ramsey, The Constitutional Law of Constitutional Amendments, 26 NOTRE DANE LAW. 185, 202-05 (1951). 
framers, ${ }^{23}$ an inquiry into the reasons underlying the distribution of powers manifested in article $\mathrm{V}$ and the limitations on those powers is required.

An understanding of the policies underlying article $V$ must begin with an examination of the framers' experiences under the Articles of Confederation. When the ex-colonists drafted the Articles they were concerned with the potentially harmful effects that a strong national government could have upon the autonomy of the states. ${ }^{24}$ The resulting document therefore emphasized the independence of the states and delegated limited authority to the national government. ${ }^{25}$ In order to ensure the continuing sovereignty of the states, the Articles of Confederation provided an amendatory process that virtually precluded any change in the substance of the Articles:

[T] ]he articles of this confederation shall be inviolaby observed by every State, and the union shall be perpetual; nor shall any alteration at any time hereafter be made in any of them, unless such alteration be agreed to in a Congress of the United States, and be afterwards confirmed by the legislatures of every State. ${ }^{26}$

This requirement of perfect consensus undermined the effectiveness of the Articles as a framework for a national government. ${ }^{27}$ All attempts to amend the document in order to strengthen that national government were defeated. ${ }^{28}$ The resulting crisis, brought about in part by the need for a strong national government and in

23 For examples of this approach see McCleskey, Along the Midway: Some Thoughts on Democratic Constitution-Amending, 66 Mrch. L. Rev. 1001, 1006 n.22 (1968).

24 See The Federaurst No. 21 (A. Hamilton).

25 See The Federautst No. 39 (J. Madison).

20 ART. OF CONFED. art. XIII (emphasis added).

27 According to [then Virginia Governor Edmund] Randolph [speaking at the Constitutional Convention], the Congress under the Confederation was impotent. Specifically: (1) it could neither prevent the states from violating international treaties, nor secure their safety in the event of war; (2) it could not prevent them from engaging in rivalrous and harmful commercial and fiscal policies; (3) it lacked the power to undertake internal improvements in agriculture and manufactures, or to secure freer intercourse among citizens; (4) it was internally divided and largely at the mercy of local views and interests; and (5) it was the juridical creature of the state legislatures.

P. Emetberg, The Phllosophy of the American Constirution 42 (1968) (footnote omitted).

28 "All attempts at amending the Articles of Confederation were frustrated by the requirement of unanimous consent by the thirteen states to any change in the constitutional system." A. Holcombe, The Constitumional Sxstem 44 (rev. ed. 1969). 
part by the Articles' inability to respond effectively to chronic political problems, ${ }^{29}$ led to the convening of the constitutional convention of 1787.30

The framers' experience with the Articles of Confederation underscored the need for an amending process in the new constitution that would allow the government and the political system to respond effectively to a changing environment. ${ }^{31}$ The framers attempted to construct a written constitution that could undergo change when "necessary," and, by implication, that could change in a manner that would "effectively" respond to a political problem. Hence they sought an amendatory process that would promote necessary and effective constitutional change. On the other hand, the framers retained their view of the consensus value as the seminal democratic value, ${ }^{32}$ of particular importance in light of their fear

29 The central government, for example, lacked the power to restore its dangerously low credit. Several amendments were considered that would have authorfzed the national government to levy import duties regarded as "indispensably necessary" for the restoration of credit; the efforts to amend, however, proved futile. See Martig, Amending the Constitution: Article V: The Keystone of the Arch, 35 Mrcr. L. Rev. 1253, 1257 (1937). The framers were directly concerned with the survival of the American republican form of government. See G. Wood, Trre CREATtON OF THE AMERTCAN REPUBLic 1776-1787, at 463-67 (1969).

$30 \mathrm{Id}$. 1256. For a view of the Articles of Confederation as "a natural outcome of the revolutionary movement within the American colonies" rather than as "the result of either ignorance or inexperience" see M. JENSEN, The ARticles of CONEEDERATION 239 (1963).

31 The framers' growing recognition of this need is illustrated most tellingly by the Convention's gradual acceptance of a congressional role in the amending process. See Kauper, The Alternative Amendment Process: Some Observations, 66 Mrch. L. REv. 903, 905 (1968). One of the early drafts expressly excluded Congress from the amending process, see note 33 infra; the appropriateness of congressional participation in the process was not accepted until the close of the debates on Article V. $2 \mathrm{M}$. Farrand, The Records of the Federal Convention of 1787 at 559 (rev. ed. 1937). In seconding a motion to reconsider the amending procedure, Alexander Hamilton explained that while the states would only favor amendments which increased their power, Congress would be especially able "to perceive," and would "be more sensible, to the necessity of amendments." Scheips, The Significance and Adoption of Article $V$ of the Constitution, 26 NOTRE DAME LAw. 46, 54-55 (1950). On the basis of this argument that Congress can best perceive a need for change, the framers gave Congress a role in the amending process, but not exclusive power as Hamilton had proposed.

32 See Tre Federalist No. 22 (A. Hamilton); No. 39 (J. Madison).

The primacy of the consensus value can be seen as resulting in the conclusion that only necessary change is permissible. Thus article V itself provides that " $[t]$ he Congress, whenever two thirds of both Houses shall deem it necessary, shall propose Amendments to this Constitution." U.S. Const. art. V (emphasis supplied). See also Dillon v. Gloss, 256 U.S. 368, 375 (1921) ("[I]t is only when there is deemed to be a necessity therefor that amendments are to be proposed ...."). The diffculty of the amendment process is itself a guarantee that only necessary, and not superfluous, amendments will be offered. See $3 \mathrm{~J}$. STORY, COMMENTARIES ON THEE Constitution of the United States 688-90 (1833). See also The Federai,ist No. 43 (J. Madison). 
of abuse of power by the national government or by large states. ${ }^{33}$ Thus the framers desired to further, through article $V$, the two not entirely compatible goals of consensus, which restrains power, and necessary and effective change, which requires unrestrained power. This dilemma was resolved by resort to the paradigm of American governmental structure: a functional separation of powers. Congress, "sensitive to the necessity of amendments," 34 was granted the power to determine when an amendment was needed and to determine the mode of ratification, ${ }^{35}$ and, implicitly from the power to "propose" amendments, the power to determine what form of amendment would be effective. The States were granted the power of ratification ${ }^{36}$-to confirm popular support for the congressional perception of and solution for the problem. ${ }^{37}$ Moreover, the percentage of states that must ratify an amendment before it may become effective was set at seventy-five, in contrast to the requirement of unanimity under the Articles: consensus would still be advanced, but change would be facilitated. Thus the separation of powers promised to check abuses by either branch, while the functional assignment of powers promised to achieve most effectively, within the constraint of separation, the dual goals of consensus and necessary and effective change. ${ }^{38}$

This understanding of the framers' design gives article $\mathrm{V}$ a more coherent gloss. Article V's assignment of the "proposal" power to Congress assumed Congress's superior ability as the national legislature to discern flaws of a national dimension in the American political structure and to ascertain the type of amendment that would most effectively remedy those problems. Article V's assignment of "ratification" power to the states turned on their closer

33 See, e.g., C. Merriam, The Wrutten Constitutron and the Unwritten Atritude 6-7 (I931).

As mentioned in note 31 supra, one of the early drafts of what came to be article $\mathrm{V}$ expressiy excluded the national legislature from the amending process: "That provision ought to be made for amending the system now to be established, without requiring the assent of the National Legislature." I M. FArRand, supra note 31 , at 121 . Further illustrating the fear that national power would by its very nature conflict with the states' best interests, the framers constructed Article $V$ so that the states would be able to amend the Constitution without congressional action. See Kauper, supra note 31, at 905. As to the fear of abuse of the states' power, the framers, although not requiring unanimous state approval as in the Articles of Confederation, did reject a proposal for a two-thirds majority in favor of threefourths. Scheips, supra note 31, at 55-56.

34 Scheips, supra note 31 , at 54-55.

35 U.S. CoNsT. art. V.

${ }^{36} I d$.

37 See Kauper, supra note 31, at 903.

38 See id. See also C. Merratam, supra note 33, at 6-7. 
proximity to the people: the states could most accurately reflect the existence vel non of consensus. But this bifurcation of amending power by function represents more than the assignment of power according to expertise; it reflects a deliberate choice to have two loci of power in order to restrain the exercise of that power. If the Constitution is to be interpreted in accordance with the intentions of its framers, the amending procedure must include at least these respective functions: Congress's proposal of an amendment must advance the goals of necessary and effective change, and the states' ratification of an amendment must promote the goal of consensus.

\section{Contemporary Relevance}

Although circumstances have changed immeasurably since the Constitutional Convention, the importance of the framers' twin goals of necessary and effective change and consensus continues. From the framers' perspective, "necessity" and "effectiveness" referred to the capacity to correct mistakes that experience would uncover in the governmental structure. Thus the framers' concern was an immediate one-the regime's survival. ${ }^{39}$ Today the need for change stems not from immediate peril of governmental collapse, but from the rapid and fundamental changes brought about through modernization.

Strict adherence to the historical meaning of the framers' values of necessary and effective change and consensus would preclude amendment to solve problems that were not inherent in the original document, but were instead brought about by a changing world. The Constitution, however, was "intended to endure for ages to come, and, consequently, to be adapted to the various crises of human affairs." 40 Its provisions are "living institutions," 41 advancing with the changing times to maintain their vitality. Nowhere can the view of the Constitution as a "living institution" be more validly applied than in the amendatory process itself-a process which, unlike any other in the Constitution, explicity contemplates

39 See note 29 supra \& accompanying text.

40 McCulloch v. Maryland, 17 U.S. (4 Wheat.) 316, 415 (1819). Indeed, the somewhat ambiguous nature of the constitutional text provides some evidence that the Constitution was intended as an adaptable document. Miller, Notes on the Concept of the "Living" Constitution, 31 GEO. WASH. L. REv. 881, 885 (1963).

41 Gompers v. United States, 233 U.S. 604, 610 (1914). See 4 Thomas JEFFERson's Works 290-92 (T. Randolph ed. 1829). This is what Chief Justice Marshall meant when he urged the nation never to forget "that it is a constitution we are expounding." McCulloch v. Maryland, 17 U.S. (4 Wheat.) 316, 407 (1819). See Missouri v. Holland, 252 U.S. 416, 433 (1920). 
change. ${ }^{42}$ Thus the framers' principle that the Constitution be amended when necessary in a manner designed to be effective derives meaning from contemporary affairs; "necessary change" is as Congress chooses to define it in deciding whether to propose an amendment, ${ }^{43}$ in order to allow the governmental structure to respond effectively to a constantly changing environment. ${ }^{44}$

Unlike the principle of "necessary and effective" change, consensus is defined specifically within the context of article $V$ as ratification by three-fourths of the states. ${ }^{45}$ Aside from that constitutional definition, consensus continues to have contemporary relevance as an important political value, functioning to maintain

42 See J. STORY, supra note 32 , at 686:

It is obvious, that no human government can ever be perfect; and that it is impossible to foresee, or guard against all the exigencies, which may, in different ages, require different adaptations and modifications of power to suit the various necessities of the people. ... A government, which, in its own organization, provides no means of change, but assumes to be fixed and unalterable, must, after a while, become wholly unsuited to the circumstances of the nation; and it will either degenerate into a despotism, or by the pressure of its inequalities bring on a revolution. It is wise, therefore, in every government, and especially in a republic, to provide means for altering, and improving the fabric of government, as time and experience, or the new phases of human affairs, may render proper, to promote the happiness and safety of the people.

${ }^{43}$ See National Prohibition Cases, 253 U.S. 350, 386 (1920). "The adoption by both houses ... of a joint resolution proposing an amendment to the Constitution sufficiently shows that the proposal was deemed necessary by all who voted for it."

The determination whether a constitutional amendment is necessary to deal effectively with a perceived problem is logically a three step process. First, it is necessary to determine that a problem of sufficient magnitude to require a constitutional solution exists. Second, the need for formal change (a constitutional amendment) as opposed to informal change must be established. See note 62 infra. Finally, it must be determined that the proposed amendment will provide an effective solution to the problem. For an articulation of the factors underlying congressional belief in the necessity of the ERA see S. REP. No. 689, 92d Cong., 2d Sess. (1972); H.R. Rep. No. 359, 92d Cong., 1st Sess. (1971). See also Brown, Emerson, Falk, \& Freedman, The Equal Rights Amendment: A Constitutional Basis for Equal Rights for Women, 80 YaxE L.J. 871 (1971).

44 Any other conclusion would imply that, aside from specific textual limitations, see note 54 infra, the Constitution contains implicit substantive limits on congressional power to propose constitutional amendments. This position has, however, been affirmatively rejected throughout American history. See United States v. Sprague, 282 U.S. 716 (1931) (article V does not require that amendments granting new direct powers over individuals be ratified in conventions); Leser v. Garnett, 258 U.S. 130 (1922) (amendments that increase the size of the electorate are within the amending power of article V); National Prohibition Cases, 253 U.S. 350 (1920) (eighteenth amendment is within amending power of article V); W. Livingston, Federalism and Constitutional Change 238-41 (1956) ("To assert that . . . limitations [on the amending power] may be shown by inference is to misunderstand the legal nature of a constitution."). Instead, the prevailing opinion is that "while the procedure for amending [the Constitution] is restricted, there is no restraint on the kind of amendment that may be offered." Whitehill v. Elkins, 389 U.S. 54, 57 (1967).

45 See text accompanying note 19 supra. 
"national" support of governmental action and to legitimate that action. The national support function, however, may not be as important today as it once was. While a major concern of the framers was that the new nation would collapse if an insufficient number of states supported change in the fundamental law, ${ }^{40}$ the risk of such collapse today is virtually nonexistent.47 On the other hand, the legitimating function of consensus may be more important today than it was two hundred years ago. When a majority approves of governmental action, the population tends to view the action as a proper exercise of governmental authority. ${ }^{48}$ Indeed, the legitimacy that attaches to an action is even greater when the consensus is ascertained through formal procedures.49 The growth in size and complexity of both the nation and the problems it faces, combined with the enormous expansion of the public sector, has given rise over the past fifteen years to a decay in governmental authority. ${ }^{50}$ Thus, the need for consensus to legitimate governmental action is greater than ever before.

The framers' fear of abuse of power is reflected in their choice of a governmental system based on federalism, which "has been a central element of the American polity from the nation's inception to the present day." ${ }^{51}$ The national government is intended as one of limited powers, with all powers not specifically delegated to the United States reserved to the states or to the people. ${ }^{52}$ This principle is reflected in the division of responsibilities in the amend-

46 See note 29 \& text accompanying notes $24-33$ supra.

47 See generally B. Scewartz, The Reins of Power 190-204 (1963).

48 See T. Low, The END of Liberalism: Ideology, Policy, aNd the Crisis of Public Autzortty 291-93 (1969). See generally A. Bickel, The Moraurty of Consent 15-18, 100 (1975) [hereinafter cited as Morality of Consent]; M. EDELiman, The Smmolic Uses of Polmitcs 1-21 (1964).

49 See Black, The Proposed Amendment of Article V: A Threatened Disaster, 72 YALE L.J. 957, 963 (1963). Referring to the amendatory process, Professor Black said: "Generally, a high degree of adherence to exact form, at least in matters of importance, is desirable in this ultimate legitimating process . . . ."

50 See generally Moraxtry of Consent, supra note 48, at 118-21. For a discussion of the changing role of American government, see M. SHapIRo \& R. TresoinN, American Constitumional Law 4-5 (4th ed. 1975).

51 Choper, The Scope of National Power Vis-à-Vis the States: The Dispensability of Judicial Review, 86 YALE L.J. 1552, 1552 (1977). See generally THE Federalist No. 45 (J. Madison), No. 46 (J. Madison); Wechsler, The Political Safeguards of Federalism: The Role of the States in the Composition and Selection of the National Government, 54 Corum. L. Rev. 543 (1954).

62 "The powers not delegated to the United States by the Constitution, nor prohibited by it to the States, are reserved to the States respectively, or to the people." U.S. CoNST. amend. X.

The continuing importance of the federalist values found in the tenth amendment was recently reaffirmed in National League of Cities v. Usery, 426 U.S. 833 (1976). 
atory process, a division designed to protect both state and national governments from the possible excesses of one another. ${ }^{53}$ To the extent that this division reflects a basic perception about the appropriate relationship between the state and federal governments, it is fundamental to the system, and, to the extent that it is protected by specific language in article $V$, it is unchangeable, except by subsequent amendment. ${ }^{54}$

\section{Application of Framers' Values to the ERA}

Any interpretation of article $V$ must advance the framers' values of necessary and effective change and consensus, while maintaining the functional separation of powers designed to further those values. Although this Comment does not suggest that the framers' values alone dictate the resolution of the time extension and rescission issues, it is necessary as a threshold consideration to understand the implications of these values for the ERA.

The value of necessary and effective change, assigned to Congress, can extend the time period available for ratification. Congress was given the proposal power because it was uniquely situated to perceive problems and devise solutions.55 It follows that Congress must be obligated to withdraw an amendment that is no longer necessary or effective; ${ }^{56}$ similarly, Congress must extend the time period, if it has imposed one, when conditions of necessity and effectiveness persist, in order to allow further consideration by the states.

The consensus value, assigned to the states, would be advanced by state rescissions. ${ }^{57}$ The state legislatures were given the ratification power because of their ability to indicate popular support; hence a state legislature must be obligated to rescind a prior ratification if the supporting consensus dissipates. Such state rescissions

53 See notes 34-38 supra \& accompanying text.

54 Article V reflects the principle of federalism in ways other than its division of amendatory responsibilities. It contains the only remaining substantive limitation on the amending power: "[N]o State, without its Consent, shall be deprived of its equal Suffrage in the Senate." U.S. ConsT. art. V. This limitation is subject to change by amendment only with the consent of all the states. See E. Dumbauld, The Constirution of the Untred States 435-36 (1964).

55 See text accompanying notes 34-35 supra.

56 Congressional imposition of a time limitation for ratification can be analyzed as a response to an obligation to withdraw an amendment that is no longer necessary or effective; it represents either a prediction of the persistence of the proposed amendment's necessity and effectiveness or a device to compel a future Congress to reconsider the proposal's continued necessity and effectiveness.

57 See L. OnFIELD, supra note 2, at 42 : "It is more democratic to allow the reversal of prior action. A truer picture of public opinion at the final date of ratification is obtained." 
would, however, tend to retard the value of necessary and effective change assigned to the Congress by making final ratification of a proposed amendment more difficult. Thus the rescission issue brings the twin values of article $\mathrm{V}$ into conflict, ${ }^{58}$ reflecting the fundamental tension between change and consensus. ${ }^{59}$

The resolution of this conflict in any particular case must depend upon the relative weight that the constitutional interpreter ${ }^{60}$ gives necessary and effective change vis-à-vis consensus. ${ }^{61}$ The weight accorded the former value will depend upon the constitutional interpreter's determination of the extent of the need for change, the extent of the proposed solution's effectiveness, and the preferability of resolving the problem through the article $\mathrm{V}$ mechanism for formal constitutional change as opposed to relying upon "informal" means of constitutional change. ${ }^{62}$ The weight

58 Arguably, consensus also causes such conflict. A short-term extension would increase consensus by giving additional states an opportunity to speak. A long-term extension, on the other hand, would diminish the likelihood of true consensus at the end of the period, thus conflicting with the value of necessary and effective change (which requires extension). See Dillon v. Gloss, 256 U.S. 368, 375 (1921).

59 An interesting theoretical question arises with respect to these values, in that it is difficult to argue that Congress would propose an amendment that it did not believe had the potential for receiving massive popular support, or that a state legislature would ratify an amendment that it did not believe to be necessary and effective. That is, although the standards are analytically separable, they are in reality inextricably intertwined. The questions therefore arise whether Congress can concern itself with consensus and whether the state legislatures can consider the necessity and effectiveness of the proposed amendment. These problems of implementation are real, but can be allayed by observing that the two values that the framers assigned to the federal and state legislatures respectively are in fact two inseparable aspects of one function-the legislative function. See C. Fruedrich, Constitutional Government and Democracy 327 (4th ed. 1968). It is the central purpose of any democratic legislature to wed policy to popular approbation. Thus it would be surprising if the Congress and state legislatures did not also consider the value not assigned to them. The framers did have a notion, however, that Congress possessed superior technical ability and that the state legislatures possessed superior perceptions of the populace, differences that are subtle but nonetheless real. See text accompanying notes 34-38 supra.

60 See text accompanying notes $125-77$ infra.

61 It has been asserted that "federalism" bars extension, 124 Cong. Rea. S16,953 (daily ed. Oct. 3, 1978) (remarks of Sen. Hatch) and allows rescission, 124 Cong. Rec. S17,049 (daily ed. Oct. 4, 1978) (remarks of Sen. Scott).

62 Informal constitutional change is the net product of efforts by the Supreme Court, lesser courts, Congress, the President, bureaucracies, political parties, and interest groups to reshape the United States Constitution. See D. MORGAN, CoNGRESS AND THE CONSTITUTION 71-98 (1966) for a discussion of three theories of informal constitutional change. This process involves much wasted effort, but it has many advantages over the formal amending process: it can be introduced tentatively and shaped gradually, it requires less political mobilization, it helps diffuse responsibility, and it provides alternative channels for change. McCleskey, supra note 23, at 1013. It is difficult overall to determine the proper mix of formal and informal constitutional change.

Some constitutional provisions are so specific that only formal amendment will suffice as, for example, the selection of Senators or the schedule 
accorded the consensus value, the seminal democratic value, will depend upon considerations of political and popular legitimacy.

Despite the tension between the framers' values of necessary and effective change and consensus, the two values can be accommodated. For example, if only one state legislature of thirty-eight were to "rescind," and if that rescission were deemed void, the consensus value would be prejudiced only slightly, while the value of necessary and effective change would be greatly advanced (although thirty-seven rescissions would so retard the consensus value as to militate that rescission be deemed constitutional, notwithstanding the degree of advancement of necessary and effective change). The constitutional interpreter's resolution of the tension between the framers' values in the context of the extension and rescission issues thus will depend upon the factual circumstances at hand.

\section{B. Contemporary Values}

Under the traditional method of constitutional interpretation, an analysis of the framers' intent, such as that presented above, ${ }^{63}$ would end the inquiry.64 This approach has, however, proved difficult to utilize because of the inadequacy and questionable accuracy of historical materials. ${ }^{65}$ More importantly, this method of constitutional construction is frequently deemed inadequate because of its inherent inflexibility; ${ }^{60}$ if values other than those of the framers cannot be considered, the Constitution will have a static, never-changing content, and will be incapable of adapting to a changing environment without frequent formal amendment.

for congressional sessions. In other cases, the formal amending process is a kind of alternate weapon to be drawn only when the agents of informal change are too hostile or too divided, exemplified by the hostility of the courts in delaying the income tax for two decades. And too, because formal changes are paramount over informal ones, they are often desired as a means of fixing some policy or principle more securely. When the leading agents of informal change are not politically responsible it would seem particularly important to provide a relatively liberal amending process. On the other hand, when those agents are popularly chosen one can safely tolerate a much more rigid procedure for formal amendments.

Id. There is no final answer to the question of the proper mix of formal and informal constitutional change. The answer depends on the specific factors of any given situation; thus the answer will vary from proposal to proposal, and from issue to issue.

${ }^{63}$ See text accompanying notes 19-62 supra.

64 That approach views the words and intent of the framers as the sole factors in constitutional interpretation. See note 23 supra \& accompanying text.

65 See Munzer \& Nickel, Does the Constitution Mean What It Always Meant?, 77 CoLUM. L. Rev. 1029, 1032 (1977).

BB See generally id. 1032-33. 
In order to allow the Constitution to maintain its vitality, it must be interpreted in a manner that considers not only the framers' values, but also fundamental contemporary values. The constitutional interpreter, be it Congress or the Court, ${ }^{67}$ must therefore identify those contemporary values that are likely candidates for incorporation into the relevant constitutional provision. ${ }^{68}$ In choosing these values, the interpreter can look to the gloss that history has added to the provision in question; ${ }^{69}$ if history has not spoken in a meaningful way (as it has not in the context of article $V$ ), ${ }^{70}$ the interpreter faces an open question with only the broad sweep of history and the development of constitutional principles as a guide.

Once these values have been identified, they must be assessed in relation to the factual constitutional issues under considerationin this case, the questions of extension and rescission. Such an analysis would be analogous to that conducted above ${ }^{71}$ in the context of the framers' values: will the resolution of the factual issue significantly enhance or detract from the values identified as relevant? Finally, a balance among the various competing values, both framers' and contemporary, must be struck.

The following section of this Comment will suggest contemporary political values relevant to the ERA extension and re-

67 The choice of the body appropriate to be the ultimate interpreter is discussed at text accompanying notes 125-77 infra.

68 The contemporary values discussed in this Comment are among those that have been mentioned by commentators or in congressional debates. The list is not an exclusive one; although those values most frequently discussed have been included, it is the analytical framework rather than the particular value choice that is of primary importance to this Comment.

It has been argued that a value of stability and/or finality is of relevance to the ERA debate. See, e.g., 124 Conc. REc. S16,964 (daily ed. Oct. 3, 1978) (remarks of Sen. Metzenbaum); 124 Conc. Rec. S16,961 (daily ed. Oct. 3, 1978) (remarks of Sen. Garm); 124 Cong. Rec. S16,959-60 (daily ed. Oct. 3, 1978) (remarks of Sen. Bayh); 124 Cong. Rec. H8644 (daily ed. Aug. 15, 1978) (remarks of Rep. Holtzman); 124 Cong. Rec. H8640 (daily ed. Aug. 15, 1978) (remarks of Rep. Tucker). These values have not been included in the proposed analytical framework, however, because they add nothing to an understanding of article $V$ that is not already clearly reflected therein. To the extent that a value of finality assumes the concept of "rest," it is antithetical to the very amending process, which contemplates ordered change when necessary. Furthermore, the formality of the amending process as set out in article $V$ reflects the framers' view that change must proceed in an ordered-or stable-fashion. Thus the concepts of finality and stability are subsumed within article $V$ considerations, and add no independent meaning to its interpretation.

69 See Youngstown Sheet \& Tube Co. v. Sawyer, 343 U.S. 579, 610 (1952) (Frankfurter, J., concurring) ("It is an inadmissibly narrow conception of American constitutional law to confine it to the words of the Constitution and to disregard the gloss which life has written upon them.").

ro See notes 2-3 supra.

71 See text accompanying notes 19-62 supra. 
scission issues and will analyze those issues in terms of each of the identified values. It should perhaps be emphasized at the outset that these are not values that relate to the substantive constitutional change proposed-that is, not to the question of equal rights for women-but rather to the process through which that change must be made.

\section{Legitimacy}

The fundamental nature of the amendatory process requires that its end product be perceived as legitimate. ${ }^{72}$ Concern for legitimacy in part underlies the constitutional requirement of consensus in the ratification process. ${ }^{73}$ Legitimacy, however, implies more than simply popular support: amendments must be considered in a fair, rational manner. ${ }^{74}$ Unprincipled, politically expedient action by the Congress will detract from this needed legitimacy.

Legislative decisions are only as sound as the legislature's compliance with its own rules of procedure. The legitimacy of congressional enactments hinges, in part, on its "conform[ing] to laws that will determine when a law has been passed." ${ }^{75}$ Moreover, "[r] ules of [legislative] . . procedure appear as restraints upon the exercise of power" by the majority, preventing the majority from gaining complete "ascendancy." 76

The value of legitimacy suggests that extension should be barred. The passage of the extension resolution may well be perceived as an unprincipled act, coming as it did only seven months before the original ratification deadline ${ }^{77}$ from a body that clearly supports ratification of the amendment. ${ }^{78}$ Furthermore, Congress expressly established a rule of procedure for ratification of the ERA: that the state legislatures limit their consideration to seven years. A congressional modification of that rule of procedure (extension of the time limitation) in the midst of its applicability would raise the spectre of the harms that this value seeks to avoid-delegitimation and the perception of manipulation. Although these harms would

72 See note 49 supra \& text accompanying notes $46-50$ supra.

73 Id.

74 " $[\mathrm{A}] \mathrm{n}$ amendment to the Constitution aimed at securing fairness should itself be secured by means that are fair ..." 124 Cong. REC. S17,317 (daily ed. Oct. 6, 1978) (remarks of Sen. Stevenson).

75 L. Fullek, The Morality of Law 115 (rev. ed. 1969).

76 C. Friedrich, supra note 59, at 368-69.

77 The original ratification deadline was March 22, 1979. See text accompanying notes 10-11 supra.

78 See Hearings, supra note 12, at 68-69 (statement of Charles L. Black, Jr.); id. 243-48 (testimony of Phyllis Schlafly). See also id. 106-07 (statement of Erwin N. Griswold). 
accompany the time extension, their impact is limited because the nature of the rule change is more or less neutral ${ }^{79}$ and the constitutionally prescribed amending procedures are relatively indeterminate.

The political value of legitimacy has little impact on the rescission issue because there is no clearly articulated a priori rule for handling rescission in either the Constitution or current statutes. ${ }^{80}$ There is a popular historical perception, however, that state rescissions are void. ${ }^{81}$ To the extent such a perception exists, congressional acceptance of rescission would appear result-oriented and tend to delegitimate the ERA; and to the extent such a perception accurately reflects historical reality, such acceptance would represent a limited manipulation of the amending process.

\section{Public Debate}

A tenet of American democratic and constitutional theory is that free competition among ideas in the public marketplace will further political wisdom. ${ }^{82}$ Although public discussion during the ratification period cannot substantially contribute to the drafting of a proposed amendment, such discussion, by various interested groups in each state, can help illuminate the wider implications of a proposal. Moreover, encouraging public debate tends to legitimate the governmental action taken subsequent to the public debates. As one commentator has observed of election campaigns, public political debate

give[s] people a chance to express discontents and enthusiasms, to enjoy a sense of involvement. This is participation in a ritual act, however; only in a minor degree is it participation in policy formation. Like all ritual, whether in primitive or modern societies ... public political debate draws attention to common social ties and to the importance and apparent reasonableness of accepting the public policies that are adopted. ${ }^{83}$

This value of public debate is best served when Congress, in its determination of the appropriate ratification period, allots suf-

79 Examples of less neutral rule changes would include lowering of the supermajority requirement or retroactive contraction of the time limitation.

80 Congress has thus far refused to speak on the rescission issue in the ERA context. See note 12 supra.

81 See note 22 supra.

82 See, e.g., Williams v. Rhodes, 393 U.S. 23, 32 (1968).

83 M. EDELMAN, supra note 48, at 3 (citations omitted). 
ficient time for the emergence and clash of all relevant points of view. Thus Congress should choose a time period that allows sufficient opportunity for a vigorous and comprehensive public debate, and should extend the time period if the proposal is still embroiled in meaningful controversy ${ }^{84}$ at the end of the original period. ${ }^{85}$ Such a determination involves the weighing of various intangible factors and is an individualized determination that must be made on a case-by-case basis.

Rescission presents a more difficult question. Public discussion of a proposed amendment tends to be most intense at the time the amendment is actually being considered by the legislature of a particular state. Although proposed amendments are submitted to all states simultaneously, state legislatures generally do not act in unison; instead, their consideration of an amendment tends to be staggered over time. Thus, states that consider a proposed amendment late in the ratification period can take advantage of the public debate in those states that have previously addressed the issue. Prohibiting rescission prevents those state legislatures that considered a proposed amendment relatively early in the ratification process from taking advantage of subsequent discussion. ${ }^{\text {se }}$ If rescission were permissible, insights produced by this later discussion might well persuade enough early ratifiers to change their positions and thereby defeat an otherwise ratified amendment. Prohibiting rescission, then, restricts the benefits to be derived from the competition of ideas in the public forum.

84 "Meaningful controversy" is not the mere repetition of arguments or points of view that have already been fully articulated, but rather the ongoing discussion that exposes or stimulates new insights or perspectives.

85 See, e.g., Hearings, supra note 12, at 64 (statement of Thomas I. Emerson). Professor Emerson stated:

The issues raised by the Equal Rights Amendment have proven to be more comprehensive than may have appeared to Congress at first. The extent to which the patterns and practices of sex discrimination pervade our society was not fully recognized by many people. Thus the number of different areas affected and the nature of the adjustments necessary have raised more issues, and the need for more discussion than was originally contemplated.

\section{As Senator Scott stated:}

The record shows . . that many of the States that ratified ERA in the early months following its submission did so without any real debate, without any committee hearings, hearing the opinions and testimony of witnesses. They jumped on the political bandwagon of the day. Yet proponents [of extension] say that the States need more time for ratifications. If that is the case, should we deny those States which ratified without debate the chance to reconsider the folly of their ratification without serious consideration of the merits of the proposed equal rights amendment?

124 Cong. Rec. S16,949 (daily ed. Oct. 3, 1978) (remarks of Sen. Scott). 
It may be argued in response that the possibility of this type of harm is remote. Rarely will so many states have acted upon an amendment in the early stages of its consideration that there will remain an insufficient number of uncommitted states to vindicate the early ratifiers' changed position; a state wishing to shift from support to rejection of a proposal can be vindicated by a vote of onefourth of the state legislatures plus one. This argument is not persuasive in the case of the ERA, however, for the bulk of the ratifications took place within a comparatively short time after the amendment's proposal. ${ }^{87}$ Thus, it appears that the purpose served by continued public debate would be advanced by permitting rescission of prior ratifications of the ERA.

\section{Responsible Decisionmaking}

It is probable that decisionmakers tend to make more informed, responsible decisions when they act with the knowledge that those decisions, once made, are irrevocable. ${ }^{88}$ Opponents of extension and rescission have accordingly asserted that rescission fosters irresponsible decisionmaking by state legislatures and, by implication, by the Congress. ${ }^{89}$ Such a claim merits serious consideration.

The assumption that an organization, like an individual, will "decide" an issue more responsibly when it knows that the decision is irrevocable is true only to the extent that the organization can be characterized as "a unitary, rational decisionmaker: centrally controlled, completely informed, and value maximizing." 90 Neither state nor federal legislatures conform to this rational actor model, however, for their structures and processes are largely incoherent. As Professor Truman has written, " $[t]$ he diffusion of power within the legislature, the multiple lines of access, and the diverse means of leverage make an inherently complex process still more complicated." 91 Another commentator has similarly observed that "the

87 Of the thirty-five states that have ratified the ERA, thirty did so within one year after its proposal by Congress. Id. S16,947 (remarks of Sen. Helms).

88 See generally G. Allison, ESSENCE of DeCisIon 27 (1971).

89 Professor Van Alstyne urged that

Congress do nothing to intimate to the States that they generally possess a power to rescind. ... The ratification of constitutional amendments is not a poker game. No state ought to consider an amendment to the Constitution under the misimpression . . . that it may do it with some sort of celerity or spontaneity because it will always have this interval of additional years while other States are looking at it to reconsider.

Hearings, supra note 12, at 138 (testimony of William Van Alstyne).

$90 \mathrm{G}$. Allison, supra note 88 , at 27 .

91 D. Truman, The Governmental Process 392 (1951). The congressional discussion of the extension resolution indicates some recognition of this legislative 
multiple points of decisionmaking cause legislative happenings to lack focus and articulation; critical actions occur at unexpected times and in out-of-the-way places. ... [L]egislative rules and procedures are cumbersome and complex, and may seem designed to help members elude responsibility for their decisions." 92

The incoherence of the legislative process is at times compensated for by the executive's leadership role in legislative affairs; ${ }^{93}$ the President and the governors are not formally involved in the constitutional ratification process, however, and so are less likely to exercise their rationalizing influence. This legislative incoherence suggests that a policy of irrevocability will, at best, marginally advance the value of responsible decisionmaking on both the state and federal levels.

There is, however, a further problem with applying this value in the specific context of the ERA. Those legislatures that have already ratified the ERA on the assumption that ratification was irrevocable have made "responsible" decisions; if reconsideration were allowed, those prior decisions would retain their "responsible" quality. New decisions, however, would be responsible only if it were clear that the reconsiderations were themselves irrevocable.94 Presumably most legislators who have voted on the ERA believed their state ratifications to be irrevocable; ${ }^{95}$ thus, prohibiting rescission effects little practical gain in responsible decisionmaking.

On the other hand, those legislatures that have already acted and assumed their decisions to be revocable can be said to have acted "irresponsibly." To bar reconsideration now would have the effect of freezing that irresponsible decision. Refusal to recognize the

irrationality. See 124 Cong. Rec. H8623 (daily ed. Aug. 15, 1978) (remarks of Rep. Heckler) ("[State legislative] [c]ommittees with few members bottled up the issue according to their parliamentary procedure and removed the opportunity for discussion.").

92 Keefe, The Functions and Powers of the State Legislature, in STATE LEGIsuatures in AMerican Politics 61 (A. Heard ed. 1966).

93 Id. 57-58. For a comprehensive discussion of the President's legislative function, see J. Kallenbach, The American Chinf Executive 320-74 (1966).

94 If that new decision, however, were in favor of rescission, then a policy of irrevocability would run contrary to the historical understanding that decisions not to ratify may be revoked. This, however, exposes a fundamental flaw in the theory of irrevocability, for, under this principle, a decision not to ratify, because it may be revoked by a subsequent vote in favor of ratification, must always be deemed "irresponsible." See Memo, supra note 20, in Hearings, supra note 12 . See also note 22 supra.

95 "The Attorneys General of Michigan, Kansas, Kentucky, Ohio, and Idaho . . . have all concluded that attempts to rescind, if Congress adhered to precedent, would be futile." 124 Cong. Rec. S16,960 (daily ed. Oct. 3, 1978) (remarks of Sen. Bayh). 
validity of state rescissions does not, then, provide more than a marginal increase in the quality of the ratification process.

\section{Reliance}

Reliance is a core value of equity and fairness, having application in many diverse settings. ${ }^{96}$ Thus, it is not surprising that it has been advanced as relevant to an analysis of the extension and rescission issues. ${ }^{97}$

A reliance interest with respect to the permanence of state legislative ratification might be asserted on behalf of those state legislators who successfully lobbied for the ERA. Such a claim of reliance is superficially plausible: most state legislators, if they considered the issue, probably adhered to the common belief that states cannot rescind.98 Reliance, however, implies more than simply a good faith belief in a given set of circumstances; these state legislators would have to demonstrate that they acted differently, believing rescission an impossibility, than they would have acted had they believed ratification to be revocable. ${ }^{99}$ To meet this behavioral requisite of reliance, it could be argued that an individual legislator supporting ratification expended all available political resources in the fight for ratification because of his belief that the issue would not recur, and that if he had believed rescission possible, he would have retained some resources to allow an effective fight against possible future attempts to rescind. The plausibility of this hypothesis is undercut by two observations about state legislators: they are generally elected for brief terms, ${ }^{100}$ and they have high turnover rates. ${ }^{101}$ A legislator, therefore, is more likely to focus on present-day concerns than on possible future events that are, at best, conjectural. Thus, it is unlikely that a legislator's belief in the

${ }^{96}$ For the seminal work on the reliance interest see Fuller \& Perdue, The Reliance Interest in Contract Damages (pts. 1 \& 2), 46 Yale L.J. 52 \& 373 (19361937).

97 Although the "reliance interest" was often mentioned in the congressional debates, see, e.g., 124 CoNG. Rec. S17,290 (daily ed. Oct. 6, 1978) (remarks of Sen. Garn), it was never clearly explained what was meant by this term. The continued reference to "[b]asic contract principles," 124 Cong. REc. S16,954 (daily ed. Oct. 3, 1978) (remarks of Sen. Hatch), however, strongly implies that it was used as described in Fuller \& Perdue, supra note 96. It is in this sense that reliance will be discussed in this Comment.

08 Although states have previously passed rescission resolutions, Congress has never chosen to give effect to these. See note 22 supra.

99 See generally Fuller \& Perdue, supra note 96, at 52-71.

100 Keefe, supra note 92 , at 67.

101 Lockard, The State Legislator, in State Legislatures in AMErucan Politics 103 (A. Heard ed. 1966). See generally D. Mahew, Congress: The ElecTORAL CoNnection (1974). 
irrevocability of ratification could have much effect on his political behavior.

Assuming, however, that state legislators did act upon a belief that ratification was irrevocable, the causal relationship between that belief and its asserted effect must still be shown. ${ }^{102}$ If individual legislators reserved present resources for future use, can it reasonably be hypothesized that those resources would have significantly affected a future battle over attempted rescission? If there is little relationship between an individual legislator's input and the legislative output, there is little reason to protect that legislator's reliance interest, for the constitutional concern here is not that the rights of individual legislators be protected, but that the legislative outcome represent the true voice of the legislature. Any individual legislator's influence is responsible for only a small part of the legislative product: the unpredictability and fortuitous influence of unexpected factors is high.103 Therefore, it is unlikely that individual efforts would play a major role in defeating an attempted rescission. Even as the number of legislators acting in reliance grows, their aggregate causal influence does not increase proportionately, for "power and authority is so fragmented and dispersed that ... it is difficult to mobilize and maintain majorities which sustain themselves throughout the stages of the legislative process." 104

The reliance argument also suggests that the congressional time extension must be barred. ${ }^{105}$ This argument is based upon the proposition that a legislator would desire only one legislative battle over the ERA because of the scarcity of political resources, and so would seek to delay legislative consideration of the issue until the end of the time available for ratification. ${ }^{108}$ A legislator ${ }^{107}$ could

102 See generally Fuller \& Perdue, supra note 96, at 52-71.

103 See M. Jewell \& S. Patrerson, The Legislative Process in the UnIted States 3-5 (3d ed. 1977).

104 Walhke, Organization and Process, in State Legislatures in Axierican Pourmics 150 (A. Heard ed. 1966).

105 See Hearings, supra note 13, at 245 (testimony of Phyllis Schlafly) ("[T]he ERA extension bill violates fundamental principles of contract law.").

106 This argument would apply to legislators opposed to the ERA, for rejection of a proposed amendment has not precluded subsequent ratification within the seven year period. For a discussion of the historical and judicial support for this position see Memo, supra note 20 , in Hearings, supra note 12, at 19-25. The argument does not apply to legislators supporting the ERA, for they undoubtedly believed ratification to preclude further consideration. See note 22 supra.

107 The reliance interest could also be asserted on behalf of relevant interest groups. This argument would be virtually identical to that made on behalf of state legislators and would generally suffer from the same flaws. Furthermore, the interest. 
thus claim that he was willing to face the ERA issue (rather than attempting to postpone its consideration) during the seven year period in reliance upon his belief that the seven year limitation was final, and that if he had known of the possibility of extension, he would have sought to delay the legislature's consideration until the end of the extended period.

This claim of reliance is more plausible than that made with respect to rescission. First, it is likely that most state legislators believed a congressional time extension to be improbable; the seven year limit had been employed nine times in the past, and had never before been extended. ${ }^{108}$ Second, it is plausible to suggest that legislators will avoid or delay consideration of divisive issues that may deplete scarce resources and threaten the paramount goal of reelection. ${ }^{109}$ Third, the causation problem does not present as great a problem here as in the rescission context, for the complexity of the legislative process fosters a tendency toward inaction. ${ }^{110}$ This systemic orientation toward delay enhances an individual legislator's ability to postpone action, and therefore gives a group of legislators seeking delay an aggregate influence out of proportion to their number. Thus state legislators could plausibly assert that they relied upon the permanence of the seven year time limitation.111

Assuming that a bona fide reliance on either the irrevocability of ratification or the seven year ratification period can be shown, such reliance cannot be termed reasonable. ${ }^{112}$ Politics is inherently unpredictable. ${ }^{113}$ More specifically, it is well established that one

asserted on behalf of such groups would be considerably weaker than it would be when asserted on behalf of state legislators; unlike the interest groups, the legislators are acting in a constitutionally assigned capacity.

108 See note 21 supra.

109 See text accompanying notes 100-01 supra.

110 See D. TRuman, supra note 91 , at 391-92.

111 The argument could be raised that protecting the legislators' right to delay, or ultimately avoid, the ERA issue runs counter to article V's policy of full public consideration of a proposed amendment. Such an argument, however, misconstrues the varied meanings of legislative delay. It is true that on the one hand, legislative delay may effectively withhold an issue from the public forum. On the other hand, legislative delay may represent a political deadlock on the issue or a deliberate quid pro quo for concessions on other legislative issues. In short, "delay" may serve both desirable and harmful purposes: it is a fundamental part of the legislative process, and is deserving of constitutional protection in the reliance context.

112 See Restatement (Second) of Contracts $\$ 90$ (1972).

To the extent that reliance is based upon a belief that both extension and rescission are constitutionally barred, the claim may appear reasonable. This, however, begs the question. A mistaken belief as to the constitutionality of an action should not be allowed to preclude an action that is itself constitutionally permissible. See 124 Cong. REc. S16,960 (daily ed. Oct. 3, 1978) (remarks of Sen. Bayh).

113 See N. Machinavelt, The Prince (3d rev. ed. 1938). 
congress cannot limit the actions of its successors. ${ }^{114}$ Thus the nature of politics and the broad congressional prerogative suggest that state legislators cannot reasonably rely on the irrevocability of their own state ratifications or on the seven year limitation.

\section{Reexamination of Article $V$ Values and Their Interrelationship in the ERA Context}

A constitutional decisionmaker, in facing any issue related to constitutional amendment, must look to the font of the constitutional amending power-article $\mathrm{V}$ of the Constitution. ${ }^{115}$ In interpreting article $\mathrm{V}$, that decisionmaker must examine not only its text and the historical values or intentions of its framers, but must additionally turn to fundamental political values of contemporary origin. ${ }^{116}$ The interpreter must first identify values appropriate for incorporation into article $\mathrm{V}$; must next assess the empirical relationships between the identified values and the factual constitutional issues in question (here, extension and rescission); and must finally scrutinize the relationships among the several values, examining which values can be advanced together with which others, which relationships pair a slight loss in one value against a greater gain in another, and which final balance is appropriate.

In the specific context of the ERA issues of extension of the ratification period and rescission of prior ratifications, six potentially relevant values were identified. Four of those six values were shown to be important to the extension and rescission issues: "necessary and effective" change, consensus, legitimacy, and public debate. The interests of reliance and responsible decisionmaking had little impact, however.

Encouragement of necessary and effective change suggests that extension should be permitted. ${ }^{117}$ The value of public debate also argues strongly in favor of extension, ${ }^{118}$ although the framers' value of consensus has little impact on the extension issue. ${ }^{119}$ Legitimacy, on the other hand, suggests that extension will be viewed as unfair, unless a principled justification can be shown. ${ }^{120}$ Thus, the constitutional decisionmaker must balance the continued need for the

114 Black, Amending the Constitution: A Letter to a Congressman, 82 YALE

L.J. 189, 191 (1977).

115 See text accompanying note 19 supra.

116 See text accompanying notes 63-71 supra.

117 See text accompanying notes 55-56 supra.

118 See text accompanying notes 82-85 supra.

110 See note 58 supra.

120 See text accompanying notes 72-79 supra. 
amendment and the need for continued public discussion concerning that amendment against the likelihood that extension will appear unprincipled. The value of public debate figured prominently in the congressional debates on the extension resolution, ${ }^{121}$ and, assuming the congressional factfinding concerning the viability of of continued debate was accurate, that value can provide a principled basis for an extension decision.

Rescission brings the framers' values of necessary and effective change and consensus into conflict. ${ }^{122}$ The resolution of that conflict will depend at least in part upon the specific factual issue involved, such as the number of states that have attempted rescission and whether rescission would alter the final disposition of the amendment. Legitimacy joins necessary and effective change in arguing against rescission; ${ }^{123}$ public debate suggests, albeit weakly, that rescission should be allowed. ${ }^{124}$

The disposition that would best reflect all relevant considerations would be to permit both extension and rescission. Only legitimacy argues strongly against extension; the force of that argument is significantly lessened if rescission is also allowed, obviating the suspicion that the legislative process is being manipulated by ERA supporters, by providing opponents with equal opportunity to benefit from the added time. Only necessary and effective change argues strongly against allowing rescission; the strength of the consensus argument in favor of rescission, however, suggests that, particularly if extension is permitted, rescission must also be allowed.

\section{Who Will Degide: Political Question Doctrine}

The eventual fate of the ERA may well depend upon whether it is the Supreme Court or the Congress that will ultimately decide the extension and rescission issues. ${ }^{125}$ Because of distinctive institu-

121 See, e.g., 124 CONG. REc. S17,025 (daily ed. Oct. 3, 1978) (remarks of Sen. Brooke); id. S16,962 (remarks of Sen. Metzenbaum).

122 See text accompanying notes 57-59 supra.

123 See text accompanying notes 60-62 supra.

124 See text accompanying notes 86-87 supra.

125 Any challenge to the constitutionality of the procedures used to ratify the ERA will most likely arise after some official action by the federal government declaring the amendment ratified. Should action be brought prior to such a declaration there would be serious problems of ripeness. See generally L. TruBE, AMERican Constitutional LAw 60-62 (1978).

The Administrator of the General Services Administration is assigned the responsibility of declaring an amendment ratified. 1 U.S.C. $\$ 106 \mathrm{~b}$ (1976). Whether the Administrator's determination is final or subject to review by the Congress is currently the subject of some debate. See 124 Cong. REc. H8639-43 (daily ed. Aug. 15, 1978); Elder, supra note 5, at 74-79. The broad range of congressional power under article $\mathrm{V}$ implies that the final word will belong to Congress. See 
tional structures and rules, each tends to assess valuational and empirical questions in different ways. ${ }^{128}$ Thus resolution of the ERA issues may vary with the interpreter even though the same interpretive framework is applied. Whether the Court or Congress will make the final decision depends upon whether extension and rescission constitute "political questions." ${ }^{127}$

Although there is a pervasive assumption that ultimately all constitutional issues will be, or should be, adjudicated by the Supreme Court, ${ }^{128}$ on occasion the Court has declared that the final determination of a constitutional question rests not with it, but with Congress or the Executive; that is, the Court has refused to reach the merits of a controversy by virtue of the "political question doctrine." This doctrine has long perplexed students of the Constitution, who have characterized its ambiguous boundaries as a "stench in the nostrils of strict constructionists," 120 and have expressed "disquietude that the line is often very thin between the cases in which the Court felt compelled to abstain from adjudication because of their 'political' nature and the cases that so frequently arise in applying the concepts of 'liberty' and 'equality." "130

The courts have generally applied three distinct tests in determining what constitutes a political question. ${ }^{131}$ The first in-

note 186 infra. This Comment proceeds under that assumption and accordingly addresses the applicability of the political question doctrine to a congressional resolution announcing the ratification of the ERA.

126 See Wechsler, Toward Neutral Principles of Constitutional Law, 73 HARv. L. Rev. I (1959). According to Professor Wechsler, there is "a vital difference between legislative freedom to appraise the gains and losses in projected measures and the kind of principled appraisal . . . that alone is the province of the courts." Id. 16.

127 See Scharpf, Judicial Review and the Political Question: A Functional Analysis, 75 Y ALE L.J. 517, $537 \mathrm{n} .69$ (1966), for a comprehensive categorization of the situations in which the Supreme Court has invoked the political question doctrine. For a less comprehensive, but more authoritative, listing, see Baker v. Carr, 369 U.S. 186, 208-26 (1962).

128 Chief Justice Marshall wrote in Cohens v. Virginia, 19 U.S. (6 Wheat.) 264, 404 (1821):

It is most true that this Court will not take jurisdiction if it should not: but it is equally true, that it must take jurisdiction if it should. The judiciary cannot, as the legislature may, avoid a measure because it approaches the confines of the constitution. We cannot pass it by because it is doubtful. With whatever doubts, with whatever difficulties, a case may be attended, we must decide if it be brought before us. We have no more right to declare the exercise of jurisdiction which is given, than to usurp that which is not given. The one or the other could be treason to the constitution.

129 L. HAND, The Bril of Rights 15 (Ist Atheneum ed. 1964).

130 Frankfurter, John Marshall and the Judicial Function, 69 HARv. L. REv. 217, 227-28 (1955).

131 See Baker v. Carr, 369 U.S. 186 (1962); G. Gunther, Cases and Materuals on Constrututional Law 472-75, 1617-25 (9th ed. 1975). Professor Weckstein, 
quires whether there exists "a textually demonstrable constitutional commitment of the issue to a coordinate political department." 132 Under the second, "some issues [present] nonjusticiable [political questions] because they cannot be resolved by judicially manageable standards, or on the basis of data available to the courts." 133 Finally, the third strand, more open-ended than the others, allows the Court to invoke the political question doctrine as a "prudential" matter when the issues are "too controversial or could produce enforcement problems or other institutional difficulties." ${ }^{134}$ These tests represent three different theories of the political question doctrine; each merits individual examination.

\section{A. Textual Commitment Doctrine}

The textual commitment approach to the political question doctrine looks to the Constitution to determine which branch of government the framers intended to serve as the final constitutional arbiter of the issue in question. ${ }^{135}$ The rationale behind this theory is simple and powerful: to protect the separation of powers. ${ }^{136}$ The Court's application of this theory is necessarily a double-edged test, for it must determine which branch has been assigned the specific constitutional issue without itself inspecting the Constitution and thereby violating the doctrine's rationale. The Court can walk the thin line of the textual commitment doctrine if it limits its determination to whether an issue in its broad outline is committed to another branch. ${ }^{137}$

however, correctly points out that the Baker standards represent "conclusory judgments rather than analytical guideposts. They serve only to reduce the level of abstraction from the general label of 'political question' to . . . more specific but no less conclusory statements . ..."Weckstein, Comments on Powell v. McCormack, 17 U.C.L.A. L. REv. 73, 80 (1969).

132 Baker v. Carr, 369 U.S. 186, 217 (1962). Some believe this constitutes the only legitimate justification for the political question doctrine. Professor Wechsler, for instance, has written: "[A]Il the political question doctrine can defensibly imply is that the courts are called upon to judge whether the Constitution has committed to another agency of government the autonomous determination of the issue raised . . . Wechsler, supra note 126, at 7-8.

133 G. Gunther, supra note 131, at 479; see Baker v. Carr, 369 U.S. 186, 217 (1962).

134 Id.; A. Bickel, The Least Dangerous Branch 183-98 (1962) thereinafter cited as Least Dangerous Branch]; Scharpf, supra note 127, at 548-49.

135 See Scharpf, supra note 127, at 538.

136 Baker v. Carr, 369 U.S. 186, 217 (1962).

137 As Justice Douglas explained in his Baker concurrence, "[w] there the Constitution assigns a particular function wholly and indivisibly to another department, the federal judiciary does not intervene." Id. 246 (Douglas, J., concurring) (footnote and citation omitted). 
To determine whether the Constitution textually commits an issue to a particular coordinate branch one must inspect the relevant constitutional provisions and the meanings of those provisions as viewed by the framers. ${ }^{138}$ While theoretically such an inspection should reveal which branch the framers intended as the final constitutional interpreter, the complexities of the constitutional arrangements and significant constitutional issues limit this method's usefulness.

The textual commitment doctrine would be most useful if the constitutional text reflected a clear intent on the part of the framers to assign a particular issue to a specific coordinate branch; such clarity would minimize the extent of the Court's "interpretation." The words of the Constitution, however, are not amenable to such a limited textual commitment test. The separation of power is only one of several organizing principles in the Constitution. Other such principles, such as the doctrine of "checks and balances," which assigns single governmental functions to more than one branch, 130 and the Constitution's failure to expressly provide for the judiciary's participation in the executive and legislative functions, ${ }^{140}$ further confound the textual commitment doctrine. These organizing principles make it difficult for a court easily to discern the framers' intent, forcing the court to engage in detailed, extensive constitutional inquiry and inviting the judiciary to interpret parts of the Constitution intended to be interpreted by another branch.

The Supreme Court's treatment of the textual commitment doctrine in Powell v. McCormack ${ }^{141}$ reflects the doctrine's problematic applicabilitr. 2.35 The Court's analysis of the Constitution's textual commitment in that case appears to violate the rationale of the textual commitment doctrine, for the Court inquired into "the

138 See, e.g., Powell v. McCormack, 395 U.S. 486, 521 (1969).

139 See 2 J. STORY, supra note 32, at 10-13.

140 The Court has not been troubled by this omission. See, e.g., Marbury v. Madison, 5 U.S. (1 Cranch) 137 (1803).

141395 U.S. 486 (1969).

142 Congressman Adam Clayton Powell sued specified Congressmen and congressional employees for injunctive relief and back pay after Congress refused to seat him because of suspected misappropriation of public funds and abuse of the New York courts. Id. 489-95. Congressman Powell claimed "that the House could exclude him only if it found he failed to meet the standing requirements of age, citizenship, and residence contained in art. I, $\$ 2$, of the Constitution-requirements the House specifically found Powell met-and thus had excluded him unconstitutionally." Id. 489. The defendants retorted, in part, that the Court could not reach the merits, for the seating or exclusion of a Congressman was "textually committed" to the appropriate House of Congress in art. I, $\$ 5$, and therefore was a political question. Id. 519 . 
scope of ... [the] textual commitment." 143 If a constitutional provision were textually committed to another branch, it would be that branch's task to determine the constitutional scope of its power. The Powell court, by enunciating the extent of the committed branch's power, eviscerated the rationale of the doctrine under which it purported to act. This is not to say that the Court cannot assess the political question doctrine in the way that it did in Powell, but only that the textual commitment approach does not permit it.

Powell gives rise to several implications for the future of the textual commitment doctrine. If the Court persists in its Powell approach, it will have sub silentio eliminated the doctrine. The Court may pull back from its Powell approach, for that case can also be understood as a response to suspected racial animus by the Congress in its exclusion of Congressman Powell. A retreat from the Powell approach would leave the Court with an internally consistent doctrine.

Powell aside, whether the extension and rescission issues are textually committed to Congress depends upon the framers' view of the congressional role in article $V$. If the proposal power was intended to be a discrete, independent function, then two considerations persuasively argue that the extension and rescission issues are textually committed to Congress. First, the framers believed Congress to be best suited for proposing amendments; ${ }^{144}$ thus, to the extent that a congressional decision to extend the time period or resolve the rescission controversy directly flows from Congress's power to propose "necessary and effective" amendments (as the extension issue certainly does) ${ }^{145}$ that decision must be deemed to fall within the textual commitment doctrine. Second, the congressional duty to propose "necessary and effective" amendments to the Constitution requires that Congress determine that some sort of "problem" exists, that the Constitution does not adequately deal with the problem, and that the Constitution can be changed to respond to the problem. The proposing function, in short, unlike any other constitutional value or function, expressly requires Congress to engage in extensive and comprehensive constitutional interpretation; absent such interpretation, it cannot suggest modifica-

143 Id. 521. The Court reversed the lower court and sustained Congressman Powell's claim, holding that "Art. I, $\$ 5$, is at most a 'textually demonstrable commitment' to Congress to judge only the qualification expressly set forth in the Constitution," id. 548, and that therefore Powell's claim was justiciable and more meritorious than that of defendants.

144 See text accompanying notes $31-35$ supra.

145 See text accompanying notes 55-56 supra. 
tions of the Constitution. If the amendatory process, therefore, relies fundamentally upon express congressional constitutional interpretation, the Court's intervention into that process would possibly undermine Congress's interpretation of the Constitution.

These arguments for the textual commitment of the extension and rescission issues to Congress must fail, however, for the framers viewed the amending process as a unitary function. The amending function was divided between Congress and the state legislatures to limit the opportunities for congressional aggrandizement. ${ }^{146}$ Thus, for example, although Congress arguably could bar rescission on the basis of its constitutional interpretation that consensus could be sacrificed for the advancement of necessary and effective change, it could more reasonably be contended that the framers' assignment of the consensus value to the states was absolute, to prevent the federal government from abusing its power. The framers' assignment of the amending power to both Congress and the state legislatures, therefore, estops any argument that the textual commitment doctrine is applicable in the article $V$ context. ${ }^{147}$

\section{B. Lack of Judicially Manageable Standards}

Even when an issue is not textually committed to one coordinate branch, the Court will nevertheless find it to be nonjusticiable if its resolution requires the application of standards that the Court is incapable of applying, due either to the broad policy nature of the issue or the significant absence of necessary information. ${ }^{148}$

Illustrative of this theory is Coleman $v$. Miller, ${ }^{149}$ in which the Court held, in part, that "the question whether by lapse of time ... [the Child Labor Amendment] had lost its vitality prior to the required ratifications" was a political question. ${ }^{\mathbf{1 5 0}}$ The Court stressed both its uncertainty regarding the standards that should be

146 See text accompanying notes 34-38 supra.

147 This conclusion can be drawn in two ways. First, and most simply, it can be assumed that the framers could not have intended only one of the two bodies to which the amending process was entrusted to make final decisions: certainly Congress alone cannot be the final arbiter. A related view is that, because the amending power was split between Congress and the states, it follows that the Supreme Court, with original jurisdiction of controversies between the United States and individual states, 28 U.S.C. $\$ 1251(\mathrm{~b})(2)(1976)$, must arbitrate disputes on such issues.

148 See note 133 supra \& accompanying text.

149307 U.S. 433 (1939).

150 Id. 456. The Child Labor Amendment was proposed by Congress to the state legislatures in 1924 without a limit on the time available for ratification. Coleman involved a constitutional challenge to the Kansas legislature's ratification, which occurred thirteen years later. 
employed to determine vitality and its incapacity to evaluate the type of information appropriate to those standards:

Where are to be found the criteria for such a judicial determination? None are to be found in Constitution or statute ... [T] $]$ he question of a reasonable time [limitation on state ratification] in many cases would involve ... an appraisal of a great variety of relevant conditions, political, social and economic, which can hardly be said to be within the appropriate range of evidence receivable in a court of justice .... On the other hand, these ... [questions] can be decided by the Congress with the full knowledge and appreciation ascribed to the national legislature of the political, social and economic conditions which have prevailed during the period since the submission of the amendment. ${ }^{151}$

The following discussion considers the manageability of standards based on the political values evolved above as relevant to the ERA issues of extension and rescission: the framers' values of necessary and effective change and consensus, and the contemporary values of legitimacy and public debate.

The framers' value of necessary and effective change ${ }^{152}$ does not provide a manageable judicial standard. The relevant considerations in assessing the advancement of this value include the degree of need for change, the certainty of the proposed amendment's success in meeting the need, the availability of informal means of constitutional change, and the relationship between the proposed change and other societal issues. These considerations defy the notion of manageable standards, both in terms of judicial competence and the kinds of information required; they are born of expediency, amenable to legislative determination. Thus, identification of an amendment as necessary to deal effectively with a problem requires "an appraisal of a great variety of relevant conditions" best left to Congress with its "full knowledge and appreciation ... of political, social and economic conditions." 153

The value of public debate can be similarly analyzed. The necessary inquiry is whether, on balance, the ratification process would benefit from a further exchange of ideas. ${ }^{154}$ Such a determination is more appropriately a legislative than a judicial func-

151 Id. 453-54.

152 See text accompanying notes 24-38 supra.

153 Coleman v. Miller, 307 U.S. 433, 453-54 (1939).

154 See text accompanying notes $82-83$ supra. 
tion, for it focuses on a broad range of policy decisions. ${ }^{155}$ Legitimacy requires an assessment of the probable effects of extension and rescission upon public opinion. ${ }^{156}$ This, too, appears more appropriate for legislative than judicial determination. To the extent that this value protects against manipulation of procedure by the majority, however, the judiciary is competent to assess the issue.

On the other hand, the framers' value of consensus ${ }^{167}$ does permit application of a manageable judicial standard. The constitutional text requires that three quarters of the state legislatures ratify a proposed amendment before it is deemed ratified. Absent rescissions, the Court need merely total the ratifications. If there are rescissions (as is the case with the ERA), the Court could resolve the dispute by reference to traditional sources of judicial information: the constitutional text and debates, case law, and history. To the extent, however, that the Court would find other considerations includible in the standard for resolving the extension or rescission issues (such as necessary and effective change or continuing public debate), that standard would be unmanageable.

\section{G. Prudential Considerations}

Although an issue may not be textually committed to a coordinate branch and the applicable decisional standards may be judicially manageable, the Court may yet decline to decide it on grounds of "prudence." 158 Such prudential restraint flows from the Court's perception of its own proper role in a democracy. ${ }^{159}$

\section{Implications of the Democratic System}

Despite the tenuous constitutional foundation for judicial review of federal legislation ${ }^{160}$ and the Court's anomolous position as a powerful non-majoritarian actor in a democratic regime, ${ }^{161}$ the Supreme Court successfully overrules federal legislation on constitutional grounds without exposing its legitimacy to attack.102 The tensions accompanying judicial intervention in a statutory case are heightened, however, when the Court intervenes in the constitu-

155 See text accompanying notes 83-85 supra.

156 See text accompanying notes 72-81 supra.

157 See text accompanying notes 24-38 supra.

158 See text accompanying note 134 supra.

${ }^{159}$ See, e.g., Frug, The Judicial Power of the Purse, 126 U. PA. L. REv. 715, 734-43 (1978).

$160 \mathrm{See}$ the discussion of Marbury v. Madison, 5 U.S. (1 Cranch) 137 (1803)

in G. GunThER, supta note 131, at 3-36.

161 Least Dangerous Branch, supta note 134, at 16-23.

162 Id. 29-33. 
tional amending process. An enacted amendment reflects a stronger expression of popular support than does a statute, for it requires a two-thirds vote by the Congress and approval by the legislatures of three-fourths of the states. Moreover, changes in the Constitution symbolically represent, to a much greater degree than do modifications of statutory law, the sovereignty of the popular will; there are no substantive limitations on the power to amend the organic law. Furthermore, amending the Constitution is the only available method for overturning a constitutional decision made by the Supreme Court. Thus, the potential for harm, both to the democratic regime and to the Court's legitimacy, if the Court were to appear to interfere in the amending process, is great. ${ }^{163}$

Providing additional support for the exercise of judicial restraint is the potentially irreparable damage that judicial invalidation of an amendment might do to an amendment's chance for eventual adoption. When the Court strikes down a federal or state statute, the political process frequently does not end; the legislature may be able to enact a new statute tailored to the Court's constitutional holdings and yet still achieve the desired social objective. Recognizing this, the Court will occasionally void a statute in order to initiate a "colloquy" with the legislative branch. ${ }^{164}$ Unlike rejection of a statute, however, the Court's rejection of a constitutional amendment or part of the amending process might permanently prevent the substance of the amendment from being accomplished. The proposal and ratification of amendments require greater resources, leadership, and time: supporters must gain twothirds approval in both houses of Congress and majority approval in the legislatures of thirty-eight states. Because the amendment process prevents easy readoption of the provision, the invalidation of an amendment takes on great political importance. The Court, then, should show greater reluctance to intercede in cases challenging an aspect of an amendment or the amendatory process than in cases of non-amendatory review.

\section{Implications of the Court's Role as a Principled Decisionmaker}

"The role of the Court and its raison d'etre are to evolve 'to preserve, protect and defend' principle." ${ }^{105}$ Occasionally the Court

163 See Black, On Article I(7)(3), supra note 21, at 896, 898 n.11 (1978); Scharpf, supra note 127, at 587-89.

164 See Least Dangerous Branch, supta note 134, at 194-97.

165 Least Dangerous Brancer, supta note 134, at 188. 
will confront cases, however, in which "even though there are applicable rules, these rules should be only among the numerous relevant considerations"; ${ }^{168}$ that is, although the controversy can be resolved by a manageable judicial standard or principle, ${ }^{167}$ the "best" resolution of the problem requires a mix of principle and expedient political considerations. Under such circumstances, Professor Bickel has argued, ${ }^{168}$ the Court should refuse to decide the merits of a case on the basis of the inadequate principle and defer to political institutions better equipped to assess the mix of considerations. ${ }^{169}$

To say that the Court shall defer to political institutions when an issue resolution demands a mix of principle and expediency is not to say that the Court should completely abandon its role as protector of principle. Professor Bickel, discussing Brown v. Board of Education's ${ }^{170}$ shunning of the political question doctrine, illustrates the relation of principle to expediency. He suggests that "[i]n ... $[B$ rown], the Southern states ... defended practices that were not merely deviations from an incomplete, partially applicable principle but the fundamental negation of an emergent one." ${ }^{171}$ Thus the more fundamental the principle, and the greater the extent to which it is abrogated, the less willing the Court should be to sacrifice the principle in deference to the political institutions.

The prudential view of the political question doctrine suggests that the Court should refuse to reach the merits of any litigation

166 Jaffee, Standing to Secure Judicial Review: Public Actions, 74 Harv. L. REv. 1265, 1303 (1961). See generally LeAst Dangerous BraNch, supra note 134 , at 183-98.

167 See text accompanying notes 148-57 supra.

168 LeAst DANGerous Branch, supra note 134, at 185-86.

169 Professor Bickel has illustrated the circumstances in which principle alone fails in his discussion of the apportionment case of Colgrove v. Green, 328 U.S. 549 (1946). See Least Dangerous Branch, supra note 134, at 192-96. Colgrove, which held the legislative apportionment problem to be a political question, was subsequently overruled by Baker v. Carr, 369 U.S. 186 (1962). Bickel argues, however, that Baker should be viewed as prodding the states into action rather than as imposing a judicial solution to the apportionment problem, see LEAST DANGEROus BraNCH, supra note 134, at 196. Thus even in the apportionment context, he argues that on balance the importance of the political issues continues to require deference to other branches:

Experience and reflection on the country as it is ... force the conclusion that the principle of equality of individual representation can be only a partial guide to the solution of the apportionment problem. And neither the Court nor anyone else has succeeded in evolving something more malleable and yet still principled, which, though present conditions might not allow for its sudden and complete execution, might yet be proclaimed as the governing rule. ... Equality of representation is one goal, and the only principled one, among many.

Id. 192.

170349 U.S. 483 (1954).

171 LeAst Dangerous Branch, supta note 134, at 194. 
concerned with the extension and rescission issues. Although the Court could employ the constitutional principle of consensus in reaching the merits, ${ }^{172}$ the values of necessary and effective change, ${ }^{173}$ legitimacy, ${ }^{174}$ and public debate ${ }^{175}$ are political, nonprincipled factors, and are inappropriate for judicial determination.

Implementation of the value of necessary and effective change requires considerations beyond the judiciary's capacity as factfinder or evaluator: the extent of the need for a proposed amendment, the extent of the effectiveness of the proposal, and the current Constitution's potential for responding to the perceived problem. An assessment of the value of continued debate requires inquiries into subjects such as the extent and quality of past political discussion on the ERA, the potential for and the likelihood of further fruitful discussion, and the impact of further debate on the decisionmaking process-subjects that are more appropriate for legislative determination. Likewise, the legitimacy value is more appropriately and expertly considered by Congress; this value requires an assessment of popular consent to changes (or, more accurately, to perceived changes) in decisionmaking procedures. Factors such as these reflect the large role of political expediency in the amending process.

The principle of consensus, ${ }^{176}$ however, cannot be trampled upon by Congress in the interest of these non-principled considerations. For example, if Congress were to declare a proposed amendment ratified in the face of nineteen state legislative rescissions, they clearly would have negated the most fundamental principle of article V; the Court could correctly hold that such a case is not a political question. If, on the other hand, only one of thirty-eight states were to rescind its ratification and Congress were to declare the amendment ratified, the Court should be reluctant to reach the merits because the principle of consensus has not been clearly violated. As the discussion of the consensus value above demonstrated, ${ }^{177}$ that value is flexible to some extent, and can be harmonized with adverse values. The question that will face the Court will be the extent to which the consensus value can be retarded and yet not be negatived.

If Congress were to refuse to recognize rescission, the four state rescissions to date would not sufficiently retard the consensus value

172 See text accompanying notes 32-38 supra.

173 See text accompanying notes 24-38 supra.

174 See text accompanying notes 72-81 supra.

175 See text accompanying notes 82-87 supra.

176 See text accompanying notes $32-38$ supra.

177 Id. 
to justify the Court's overruling Congress's political judgment; the same conclusion would certainly apply if Congress were to decide to allow rescission, for then no value examined here would be negated. Similarly, the congressional extension of time available for ratification does not substantially controvert the relevant values.

Thus the Court's roles as a non-majoritarian institution having substantial power in a majoritarian regime and as a principled decisionmaker indicate that the time extension and rescission issues of the ERA fall within the political question doctrine. In each context it is clear that the Court should generally defer resolution of any controversy concerning ratification of the ERA to the political branches, and, in disposing of the case, should not reverse any action taken by those branches on the issue.

\section{Disposition of Article V Cases}

If the Court finds that an article V "case" (in the ERA context, a challenge to the constitutionality of the time extension or to the resolution of the rescission controversy) presents a political question, the further issue remains of how to dispose of that case. If the challenge is presented to the Court before a congressional declaration of ratification, the Court should simply dismiss the case on the ground that it is a political question and await a congressional resolution of the issue. As the political question doctrine requires the Court to defer to the judgment of a coordinate branch, dismissal is the only action that the Court can take before the coordinate branch resolves the disputed issue.

If the case reaches the Court after Congress has declared the amendment ratified, ${ }^{178}$ however, the Court should then adopt the determination of the coordinate branch and apply it as settled law without considering the challenge to the congressional action on the merits. This disposition-enforcement of the coordinate branch's determination without evaluating the merits of the determinationis suggested by the nature of the political question doctrine. Although that doctrine counsels the Court to defer to a coordinate branch when it cannot resolve a dispute in an appropriately principled fashion, ${ }^{179}$ the obverse side of the logic suggests that the Court must enforce that branch's specific resolution of the dispute and all legal obligations flowing from that resolution; if the Court were to dismiss suits challenging the constitutionality of an amendment or legislation enacted pursuant thereto, the Court would in effect

178 See note 125 supra.

179 See text accompanying notes $165-77$ supra. 
eviscerate the resolution by the coordinate branch to which it had deferred. Thus congressional ratification of a proposed amendment gives rise to a new principle of decision: a ratified amendment becomes incorporated into the Constitution, and must be so declared.

This disposition is also suggested by the Court's role as a "legitimating force in society."180 Professor Bickel has noted that the Court's sustaining of congressional or executive action tends to legitimate that action, and even to convert that action into an accepted ordering principle. ${ }^{181}$ The Court should thus go to great lengths to avoid the appearance of lending approval to the extension or rescission behavior considered to be a political question, and should expressly refuse to examine the merits of the constitutional challenge. On the other hand, a refusal to declare the congressionally ratified amendment part of the Constitution would call into question the Court's willingness to enforce that part of the Constitution, undermining the document's legitimacy and possibly that of the Court itself. Hence the Court should announce the amendment to be "legitimate," but should make clear that the basis of its acceptance is the unscrutinized congressional acceptance. ${ }^{182}$

This analysis rationalizes the apparently inconsistent line of cases that have construed article V. Each of the first six cases presented to the Court involved challenges to an amendment after it had been declared ratified. ${ }^{183}$ In all six the Court affirmed the validity of the amendment, thereby respecting the congressional resolution of the issue. Although all six cases were purportedly decided on the merits, thereby departing from the suggested analysis, several are merely conclusory opinions, best explained as resulting from a desire to affirm the congressional action. ${ }^{184}$ In the seventh

180 Least Dangerous Branch, supta note 134, at 31.

181 Id. 129.

182 The Supreme Court has followed this procedure in resolving cases in which a party has asserted that a statute was improperly adopted and was therefore invalid. See Harwood v. Westworth, 162 U.S. 547 (1896); Field v. Clark, 143 U.S. 649 (1892). These cases were followed in rejecting a challenge to the validity of a state's ratification of the 19th amendment in Leser v. Garnett, 258 U.S. 130, 137 (1922). See also Scharpf, supra note 127, at 547 n.106.

183 United States v. Sprague, 282 U.S. 716 (1931); Leser v. Garnett, 258 U.S. 130 (1922); Dillon v. Gloss, 256 U.S. 368 (1921); National Prohibition Cases, 253 U.S. 350 (1920); Hawke v. Smith, 253 U.S. 221 (1920); Hollingsworth v. Virginia, 3 U.S. ( 3 Dall.) 378 (1798). See note 3 supra.

184 Hollingsworth v. Virginia, 3 U.S. ( 3 Dall.) 378 (1798) epitomizes such a conclusory opinion designed to affirm the congressional action. It is a five-line opinion rendered the day after argument articulating no justification for the exclusion of the President from the amending process, thereby contracting the clear letter of art. $1, \S 7$, of the Constitution. The opinion in the National Prohibition Cases, 
and most recent case, ${ }^{185}$ the Court was presented with a challenge to one state's ratification of a proposed amendment prior to ultimate ratification. As Congress had not yet had an opportunity to resolve the dispute by declaring the amendment ratified, the Court refused to reach the merits and dismissed the case on the grounds that it presented a political question. This result is entirely consistent with the above analysis and is the proper disposition of any litigation concerning the ERA prior to a congressional resolution of ratification. Thus, in sum, the Court should take action only to enforce a congressional declaration of ratification ${ }^{186}$ and should refuse to address the merits of the amending process employed in the adoption of the ERA in any cases that may come before it.

253 U.S. 350 (1920), is equally conclusory, again offering no reasoning for its result. See id. 388 (White, C.J., concurring).

Moreover, in Leser v. Garnett, 258 U.S. 130, 137 (1922), the Court explicitly recognized its obligation to enforce the determination of ratification made by another branch of government, without investigating the merits of that determination; and in United States v. Sprague, 282 U.S. 716, 730 (1931), the Court denied a challenge to the mode of enacting the 18th amendment by concluding that " $t]$ he choice, therefore, of the mode of ratification, lies in the sole discretion of Congress." These holdings are in compliance with the proposed disposition of an ERA case.

185 Coleman v. Miller, 307 U.S. 433 (1939).

186 It has been assumed that a Supreme Court decision to defer to the responsible political institution would mean deferring to Congress. There are other contending political institutions, however: the state legislatures, the President, and even the administrator of the General Services Administration (GSA).

The primary claimants for the role of constitutional interpreter of article $V$ other than Congress are the state legislatures, whose claim derives from their constitutionally-mandated role in the amending process. Congress, however, is the preferable constitutional interpreter in regard to the time extension issue. The impact of that decision is national in scope; moreover, the consideration whether the national marketplace of ideas might be benefited requires information of national breadth, more accessible to the Congress than to any state legislature. The rescission issue is also best decided by Congress. Although the framers assigned to the state legislatures the task of ascertaining the existence of consensus, this task extends only to the measurement of support within each state, and not to the larger assessment of the necessary consensus throughout the nation.

The President can also claim some right to influence the determination of the rescission and time extension issues under art. $1, \S 7$, of the Constitution. See Black, On Article I(7)(3), supra note 21, at 896. However, Hollingsworth v. Virginia, 3 U.S. ( 3 Dall.) 378 (1798), is established precedent to the contrary.

Finally, the GSA administrator may be able to determine the rescission and time extension issues, as he is currently empowered to publish the amendment when ratified. See note 125 supra. The statute is silent as to how the administrator is to determine ratification, see 1 U.S.C. $\$ 106 \mathrm{~b}$ (1976). Accordingly, the administrator may be able to argue that the statute provides him power to determine ratification. Because the statute was enacted as a part of a reorganization of government printing responsibilities, however, it seems most unlikely that Congress intended to delegate the power to determine ratification to the administrator. See Elder, supra note 5. Accordingly, the Court should recognize a congressional declaration of ratification as the definitive legal statement on the rescission and time extension issues. 


\section{Conclusion}

The proposed analysis of article $V$ suggests that neither extension of the ratification period for the ERA nor recognition of state rescission is inconsistent with its underlying values. Article V grants to Congress wide-ranging authority in the amendatory process, limited only by the specific language of the Constitution and the preeminent value of consensus.

The expansive quality of article $V$ and the political nature of its underlying value choices make it unlikely that the Court will intrude into the amendatory process unless the fundamental values of article $\mathrm{V}$ are threatened. The Congress, then, will likely serve as the final constitutional interpreter of the extension and rescission issues. 